\title{
BIOGEOGRAPHICAL RELATIONSHIPS OF THE EEL PARASITE ANGUILLICOLA CRASSUS REVEALED BY RANDOM AMPLIFIED POLYMORPHIC DNA MARKERS (RAPDS)
}

\author{
I. RAHHOU (1, 2), S. MORAND (3), R. LECOMTE-FINIGER (4) AND P. SASAL (2)
}

(1) Laboratoire d'hydrobiologie et Écologie Générale, Faculté des Sciences, Université Mohamed Premier, BP 524, Oujda, Maroc.

(2) Laboratoire de Parasitologie Fonctionnelle et Évolutive, UMR 5555 CNRS, Université de Perpignan, 52, avenue Paul Alduy, 66860 Perpignan Cedex France. E-mail : sasal@univ-perp.fr

(3) CBGP (Centre de Biologie et de Gestion des Populations), Campus International de Baillarguet, CS 30 016, 34988 Montferrier-sur-Lez Cedex, France.

(4) École Pratique des Hautes Études, UMR 8046 CNRS Université de Perpignan, 52, avenue Paul Alduy, 66860 Perpignan Cedex, France

Reçu le 2 septembre 2004

Accepté le 11 juillet 2005

Received September 2, 2004 Accepted July 11, 2005

\begin{abstract}
The introduction and the rapid expansion of the nematode Anguillicola crassus in Europe in the early 80's is one of the causes of the decrease of the European eel, Anguilla anguilla, populations. The aims of this work were to study, using RAPD markers, the genetic diversity and the population relationships between 16 populations of Anguillicola crassus originating from Europe (11 populations coming from the Mediterranean Sea or facing the Atlantic Ocean), Morocco, Japan (the original region of the parasite) and the USA (the most recently invaded place). Overall, 7 primers were useful and 32 reproducible bands showed polymorphism. Our results revealed a significant population differentiation between populations coming from the Mediterranean Sea and the other populations. We did not find a significant relationship between the genetic and the geographic distances suggesting multiple events of introduction. This was confirmed by the significant relationship found between the geographical distance and the dates of introduction. We also discuss the origin of the parasite in North America.
\end{abstract}

Key-words: Eels, Anguillicola crassus, RAPD, invasive species, parasites.

\section{ÉTUDE BIOGÉOGRAPHIQUE DU PARASITE DE L'ANGUILLE, ANGUILLICOLA CRASSUS À L'AIDE DE MARQUEURS RAPD}

\section{RÉSUMÉ}

L'introduction dans le début des années 1980 et la rapide expansion en Europe du nématode parasite Anguillicola crassus est une des causes naturelles du déclin des populations d'anguille européenne. Les objectifs de ce travail étaient d'étudier à l'aide de marqueurs RAPD, la diversité génétique et les relations entre 16 populations d'Anguillicola crassus provenant d'Europe (11 populations provenant de la Mer Méditerranée ou de la 
façade Atlantique), du Maroc, du Japon (la région d'origine du parasite) et des EtatsUnis (la région la plus récemment envahie). Sur l'ensemble des amorces utilisées, 7 se sont révélées utilisables et ont donné 32 fragments reproductibles et polymorphes. Nos résultats montrent qu'il est possible de différencier de façon significative les populations Méditerranéennes d'Anguillicola crassus des autres populations. Nous n'avons pas trouvé de relation significative entre les distances génétiques et les distances géographiques laissant supposer l'existence de plusieurs évènements d'introduction. Ce résultat est confirmé par la relation significative que nous avons mise en évidence entre les distances géographiques et les dates d'introduction supposées. Nous discutons aussi l'origine probable des parasites introduits en Amérique du Nord.

Mots-clés: Anguille, Anguillicola crassus, RAPD, espèce invasive, parasites.

\section{INTRODUCTION}

The development of the fish farming and more particularly of eel culture has led numerous countries of Europe and North America to import eels Anguilla sp. from East Asia. The introduction of the Asian species Anguilla japonica from Taiwan (KØIE, 1988) has led to the simultaneous introduction in the early 80's of the nematode Anguillicola crassus, a parasite of the swimbladder (KØIE, 1991; KOOPS and HARTMAN, 1989). The first case of anguillicolosis in Europe has been described in Germany (NEUMANN, 1985; PETERS and HARTMANN, 1986). Since then, the data relative to its extension have been regularly published and has recently been update by KIRK (2003). The recent association between Anguillicola crassus and Anguilla anguilla is characterized by an important pathogenicity (KNOPF and MAHNKE, 2004; MÜNDERLE et al., 2004; SURES and KNOPF, 2004). Eels become infected by feeding on infected copepods or on reservoir paratenic hosts, the parasite migrates into the swimbladder and feed on the blood of the fish. The nematode is responsible for important eel losses in European and North African countries (MOLNAR et al., 1991, LEFEBVRE et al., 2002).

Migrations of definitive host and its presence in a wide range of environments, has strongly contributed to the rapid colonisation of the parasite. For example, the epidemiological investigation done by EL HILALI et al. (1996) on one of the estuaries leading to the Mediterranean Sea in Morocco showed that none of the eels studied were affected by Anguillicola crassus. The last epidemiological survey in the same place (RAHHOU et al., 2001) revealed that the rapid geographical spreading out is also linked to other favourable factors, like a prolific fertility towards the intermediate hosts and the important numbers of paratenic hosts (16 teleost species according to THOMAS and OLLEVIER, 1992 and BLANC, 1994). MORAVEC (1996) has shown that this parasite can also use a mollusc of the genus Galba as paratenic host. Thus, one important remaining question is to know the number and the origin(s) of introduction of this parasite species in Europe, North Africa and North America.

The development of random amplified polymorphic DNA (RAPD) markers by WILLIAMS et al. (1990) and WELSH and McCLELLAND (1990), has provided a tool for the investigation of genetic variation. It is a PCR-based technique using short arbitrary primers to amplify target DNA under low stringency conditions. The utility of RAPDs for genetic characterisation of parasites populations has been demonstrated by several authors (BARRAL et al., 1993; LANGAND et al., 1999, KJØLNER et al., 2004).

The aim of our work was to use RAPD analysis to study genetic diversity of A. crassus collected from different geographic locations in order to estimate the dynamic of the invasion through its geographical range. Considering the limits of the RAPD technique and the relatively limited sample size for the populations studied, our study did not intend to be a population genetic study of Anguillicola crassus, but rather a preliminary 
assessment of it. The results may also help to explain the way of dissemination and spread of this parasite species.

\section{METHODS}

\section{Parasite collection and conservation, and DNA extraction}

Sixteen sites have been sampled for wild eels, one in Switzerland (1), two in NorthAmerica from Cheasapeake Bay (2 and 3), two in Japan not far from Tokyo (4 and 5), two in Holland (ljssel Lake = 6 and Friesland =7), one in Sweden (8), one in Morocco in the Moulouya river (9), one in Greece (10), three on the French Atlantic coast in Brittany (11, 12 and 13), and three on the French Mediterranean coast (Salses Leucate Lagoon $=14$ and Vaccares Lagoon 15 and 16) (Figure 1 and Table I). Collected Anguillicola crassus were preserved in $90 \%$ alcohol.

DNA was extracted from each worm according the protocol used by BARRAL et al. (1993) with minor modifications. Each adult worm was carefully dried on an absorbent paper in order to eliminate the excess of alcohol then homogenised by a pestle adapted to a microcentrifuge tube in $50 \mu \mathrm{L}$ of extraction solution $(150 \mathrm{nM} \mathrm{NaCl}, 10 \mathrm{mM}$ Tris- $\mathrm{HCl}$, $\mathrm{pH}$ 8.0, $1 \mathrm{mM}$ EDTA and $88 \mathrm{mM}$ sucrose). Then, $50 \mu \mathrm{L}$ of extraction solution, $15 \mu \mathrm{L}$ of proteinase $\mathrm{K}(10 \mathrm{mg} / \mathrm{mL})$ and $10 \mu \mathrm{L}$ of SDS $(1.0 \mathrm{~g} / \mathrm{mL})$ were added. The solution was incubated 2 hours at $56^{\circ} \mathrm{C}$ in order to break cells membrane and to digest the proteins. DNA extraction was performed by addition of $125 \mu \mathrm{L}$ of phenol and shaked during 10 minutes prior to the addition of $125 \mu \mathrm{L}$ of chloroform-isoamyl alcohol. The tubes were centrifuged at $6000 \mathrm{~g}$ during 15 minutes at room temperature. The aqueous phase containing the DNA was conserved. The precipitation of DNA was realized by the addition of $10 \%$ sodium acetate $3 \mathrm{M}(\mathrm{pH} 5.2)$ and 3 volumes of cold absolute ethanol. After 2 hours at $-80^{\circ} \mathrm{C}$ or at $-20^{\circ} \mathrm{C}$ overnight, tubes were centrifuged at $9000 \mathrm{~g}$ during 20 minutes at $4^{\circ} \mathrm{C}$. They were emptied and washed with $1 \mathrm{~mL}$ of $70 \%$ ethanol then centrifuged, emptied, dried and finally DNA pellets were re-suspended in $100 \mu \mathrm{L}$ of $\mathrm{H}_{2} \mathrm{O}$.

\section{PCR AMPLIFICATION}

In order to identify the suitable primers, thirty oligonucleotides (from kits A, B and G; Operon Technologies Inc. USA) were tested to detect variability between individuals. PCR reactions were prepared in a volume of $25 \mu \mathrm{L}$ containing 1 unit Taq-DNA polymerase (Promega), $2.5 \mu \mathrm{L}$ Taq polymerase 10X buffer (Promega), $2.5 \mathrm{mM} \mathrm{MgCl} 2,100 \mu \mathrm{M}$ of each dNTP, $1 \mathrm{mM}$ of primer and approximately $25 \mathrm{ng}$ of total DNA. Amplifications were carried out for 40 cycles in a Hybaid ${ }^{T M}$ DNA Thermal cycler and began by an initial denaturation at $92^{\circ} \mathrm{C}$ for $3 \mathrm{~min} 50 \mathrm{sec}$. Each cycle included the following steps: $1 \mathrm{~min}$ at $92^{\circ} \mathrm{C}$ for the denaturation, $2 \mathrm{~min}$ at $35^{\circ} \mathrm{C}$ for the annealing and $2 \mathrm{~min}$ at $72^{\circ} \mathrm{C}$ for the extension. The extension time was increased to 5 min during the final cycle in order to complete the primer extension. The resulting amplified products were analysed by electrophoresis in agarose gels (1\%) and stained with ethidium bromide. They were visualised by using ultraviolet light.

\section{Data analysis}

RAPD patterns generated by the primers were scored (1) when the band was present and (0) when the band was absent. The diversity based on phenotypic frequencies was calculated for each marker with the Shannon index (KREBS, 1999) according to the formula:

$$
\mathrm{H}=-\Sigma(\text { pi In pi) }
$$

With pi the frequency of the marker $i$. 


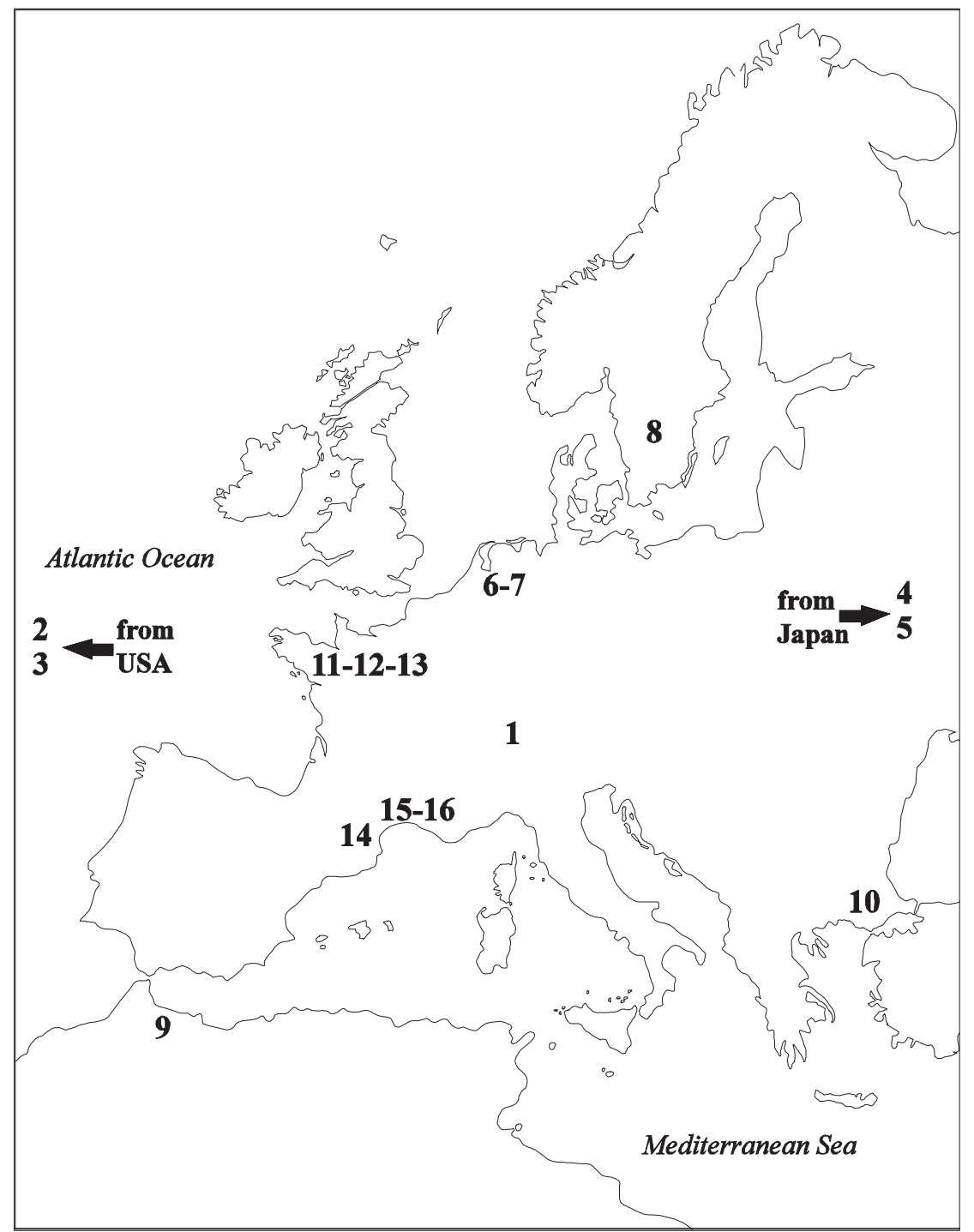

Figure 1

Geographical distribution of the sampled populations of Anguillicola crassus. $1=$ Switzerland; 2 and $3=$ North-America; 4 and $5=$ Japan; 6 and $7=$ Holland; 8 = Sweden; 9 = Morocco; 10 = Greece; 11, 12 and 13 = Atlantic coast of France; 14, 15 and $16=$ Mediterranean coast of France. Numbers are the same as in table $I$.

\section{Figure 1}

Distribution géographique des populations d'Anguillicola crassus échantillonnées. 1 = Suisse ; 2 et $3=$ Amérique du Nord ; 4 et $5=$ Japon ; 6 et $7=$ Pays-Bas ; 8 = Suède ; $9=$ Maroc ; $10=$ Grèce ; 11,12 et $13=$ côtes atlantiques françaises ; 14,15 and 16 = côtes méditerranéennes françaises. Les numéros sont les mêmes que ceux du tableau $\mathrm{I}$.

Canonical analysis was carried out using individual data of presence/absence of RAPD markers. Permutation tests showed whether the groups actually exist or not, and which were the axes which discriminate between groups. The ratio between the sums of all canonical eigenvalues (given by the correspondence analysis) represented the part of the variance due to groups. Software CANOCO (version 3.11) was used to perform canonical analysis and permutation tests (TER BRAAK, 1986). 
A Mantel t-test (software R4, program Mantel, Casgrain and Legendre available at http://www.fas.umontreal.ca/biol/casgrain/en/labo/R/v4/) was carried out to detect a correlation between geographical distances and Euclidean distances based on the frequencies of RAPD markers for each population pair. Moreover, we tested, with the same method, a potential relationship between genetic distances and the year of first record of $A$. crassus in the studied areas.

\section{RESULTS}

A total of 178 Anguillicola crassus have been studied with a minimum of 9 worms of a single sampled locality (Table I). Among the primers tested, 7 primers yielded a positive and repeatable pattern of amplification products and were adopted for our study (Table II).

\section{Table I}

Specific localities, host species and sample sizes of the studied Anguillicola crassus. Sixteen sites have been sampled, one in Switzerland (1), two in NorthAmerica (2 and 3), two in Japan (4 and 5), two in Holland (6 and 7), one in Sweden (8), one in Morocco (9), one in Greece (10) and six in France (3 on the Atlantic coast 11, 12 and 13; and 3 on the Mediterranean coast 14, 15 and 16).

\section{Tableau I}

Situation géographique, espèce hôte et nombre d'Anguillicola crassus étudiés. Seize stations ont été échantillonnées, une en Suisse (1), deux en Amérique du Nord (2 et 3), deux au Japon (4 et 5), deux aux Pays-Bas (6 et 7), une en Suède (8), une au Maroc (9), une en Grèce (10) et six en France (3 sur la côte Atlantique 11, 12 et 13; et 3 sur la côte Méditerranéenne 14, 15 et 16).

\begin{tabular}{|c|c|c|c|c|}
\hline $\begin{array}{l}\text { Population } \\
\text { number }\end{array}$ & Localization & $\begin{array}{l}\text { Host } \\
\text { species }\end{array}$ & $\begin{array}{c}\text { Fish } \\
\text { sample } \\
\text { size }\end{array}$ & $\begin{array}{c}\text { Parasite } \\
\text { sample } \\
\text { size }\end{array}$ \\
\hline 1 & Switzerland $47^{\circ} 30^{\prime} \mathrm{N} ; 07^{\circ} 40^{\prime} \mathrm{E}$ & A. anguilla & 3 & 9 \\
\hline 2 & USA $36^{\circ} 15^{\prime} \mathrm{N} ; 7^{\circ} 20^{\prime} \mathrm{W}$ & A. rostrata & 3 & 9 \\
\hline 3 & USA $36^{\circ} 15^{\prime} \mathrm{N}$; $76^{\circ} 20^{\prime} \mathrm{W}$ & A. rostrata & 3 & 9 \\
\hline 4 & Japan $35^{\circ} 45^{\prime} \mathrm{N}$; $139^{\circ} 50^{\prime} \mathrm{E}$ & A. japonica & 3 & 9 \\
\hline 5 & Japan $35^{\circ} 45^{\prime} \mathrm{N}$; $139^{\circ} 50^{\prime} \mathrm{E}$ & A. japonica & 3 & 9 \\
\hline 6 & Holland $53^{\circ} 01^{\prime} \mathrm{N}$; $05^{\circ} 45^{\prime} \mathrm{E}$ & A. anguilla & 3 & 9 \\
\hline 7 & Holland $53^{\circ} 32^{\prime} \mathrm{N}$; $05^{\circ} 15^{\prime} \mathrm{E}$ & A. anguilla & 3 & 9 \\
\hline 8 & Sweden $58^{\circ} 00^{\prime} \mathrm{N} ; 1^{\circ} 05^{\prime} \mathrm{E}$ & A. anguilla & 3 & 15 \\
\hline 9 & Morocco $34^{\circ} 15^{\prime} \mathrm{N}$; $03^{\circ} 20^{\prime} \mathrm{W}$ & A. anguilla & 5 & 22 \\
\hline 10 & Greece $39^{\circ} 06^{\prime} \mathrm{N} ; 2^{\circ} 55^{\prime} \mathrm{E}$ & A. anguilla & 3 & 9 \\
\hline 11 & France Bois-Joli $48^{\circ} 45^{\prime} \mathrm{N}$; $02^{\circ} 01^{\prime} \mathrm{E}$ & A. anguilla & 3 & 9 \\
\hline 12 & France Vilaine $47^{\circ} 29^{\prime} \mathrm{N}$; $02^{\circ} 10^{\prime} \mathrm{W}$ & A. anguilla & 3 & 9 \\
\hline 13 & France Vilaine $47^{\circ} 29^{\prime} \mathrm{N}$; $02^{\circ} 10^{\prime} \mathrm{W}$ & A. anguilla & 3 & 9 \\
\hline 14 & $\begin{array}{l}\text { France Salses-Leucate } 42^{\circ} 49^{\prime} \mathrm{N} \text {; } \\
03^{\circ} 04^{\prime} \mathrm{E}\end{array}$ & A. anguilla & 3 & 9 \\
\hline 15 & France Vaccares $43^{\circ} 32^{\prime} \mathrm{N}$; $04^{\circ} 30^{\prime} \mathrm{E}$ & A. anguilla & 5 & 16 \\
\hline 16 & France Vaccares $43^{\circ} 32^{\prime} \mathrm{N}$; $04^{\circ} 30^{\prime} \mathrm{E}$ & A. anguilla & 5 & 17 \\
\hline
\end{tabular}


A total of 32 reproducible bands ranging from approximately 200 to $1200 \mathrm{bp}$ showed polymorphism among the parasite specimens.

We calculated the average diversity on the set of markers for each population (Table III). It ranged from 0.057 (for $A$. crassus from France Vilaine) to 0.227 (for parasites from Switzerland). The small values of diversity corresponded to parasite populations with low genetic diversity whatever the primer used, while high values of diversity are typical

Table II

Polymorphic RAPD primers used in this study.

\section{Tableau II}

Amorces polymorphes utilisées dans cette étude.

\begin{tabular}{cc}
\hline Primer code & Sequence 5'-3' \\
\hline OP-A20 & GTTGCGATCC \\
OP-B08 & GTCCACACGG \\
OP-G05 & CTGAGACGGA \\
OP-G10 & AGGGCCGTCT \\
OP-G16 & AGCGTCCTCC \\
OP-G17 & ACGACCGACA \\
OP-G19 & GTCAGGGCAA \\
\hline
\end{tabular}

Table III

Phenotypic diversity (Shannon index) calculated for all the polymorphic RAPD markers for the different population studied.

\section{Tableau III}

Diversités phénotypiques (indice de Shannon) calculées sur l'ensemble des marqueurs RAPD polymorphes pour les différentes populations étudiées.

\begin{tabular}{ccc}
\hline $\begin{array}{c}\text { Population } \\
\text { number }\end{array}$ & Geographic origin & Shannon index \\
\hline 1 & Switzerland & 0.227 \\
2 & USA & 0.086 \\
3 & USA & 0.141 \\
4 & Japan & 0.111 \\
5 & Japan & 0.126 \\
6 & Holland & 0.126 \\
7 & Holland & 0.210 \\
8 & Sweden & 0.144 \\
9 & Morocco & 0.163 \\
10 & Greece & 0.162 \\
11 & France Bois-Joli & 0.086 \\
12 & France Vilaine & 0.057 \\
13 & France Vilaine & 0.170 \\
14 & France Salses-Leucate & 0.087 \\
15 & France Vaccares & 0.144 \\
16 & France Vaccares & 0.150 \\
\hline
\end{tabular}


of parasite populations with high genetic diversity. In order to confirm results obtained on the existence of a significant difference between populations of $A$. crassus, a canonical analysis of correspondences has been realized on the 16 parasite populations.

In a first attempt, we considered only the 11 European populations. The results (Figure 2) confirmed a significant differentiation of the populations corresponding to $32.7 \%$ of the total variance. 200 permutations indicated that there was a significant differentiation

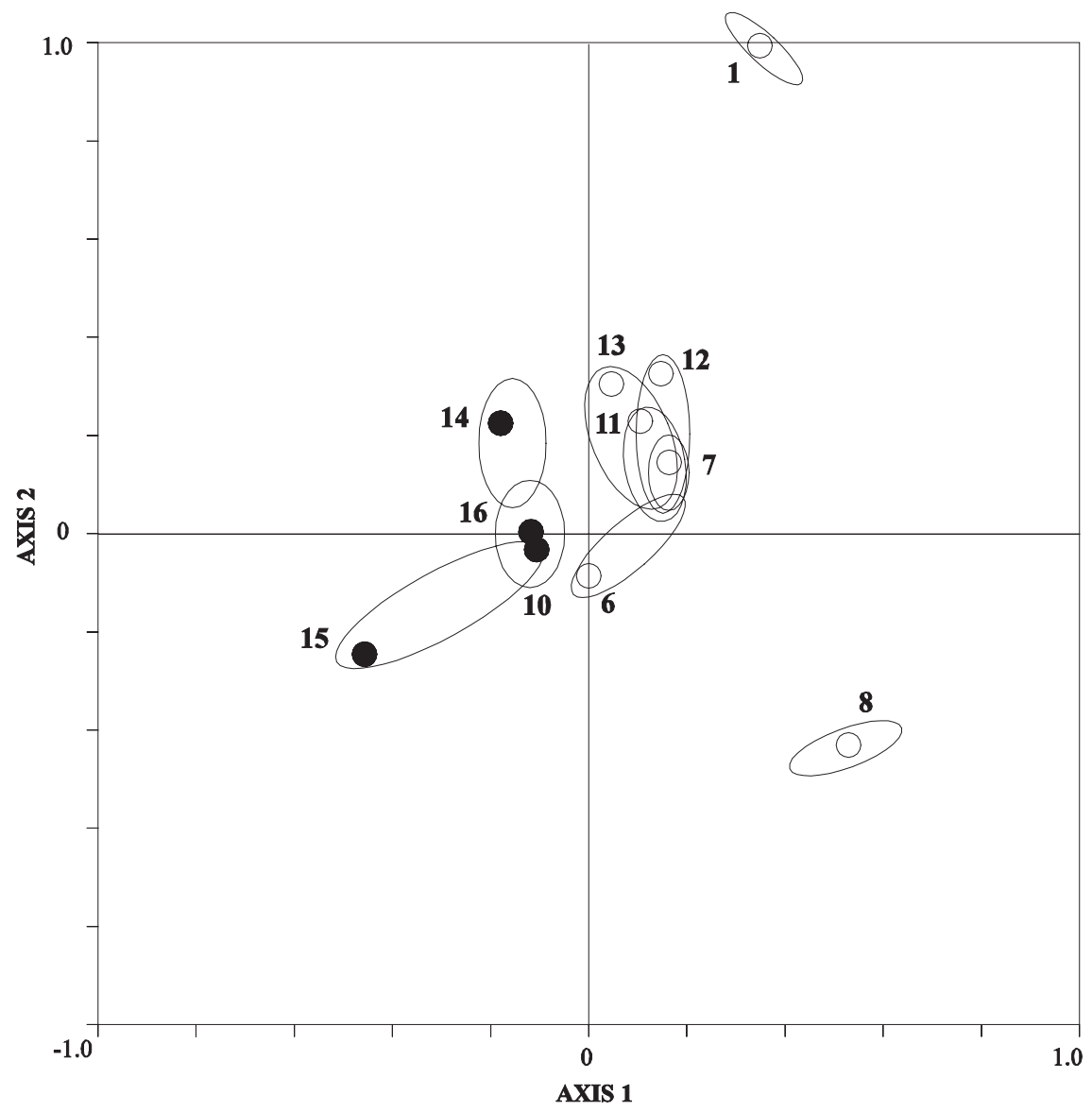

Figure 2

Canonical representation of the 11 European populations of Anguillicola crassus sampled. The two first axes represent respectively $35.2 \%$ and $18.5 \%$ of the canonical inertia. Ellipses represent $95 \%$ confidence intervals around the centroids. $1=$ Switzerland; 6 and $7=$ Holland; $8=$ Sweden; $10=$ Greece; 11 , 12 and $13=$ Atlantic coast of France; 14, 15 and $16=$ Mediterranean coast of France. Numbers are the same as in table I. Black dots represent Mediterranean populations and white dots all other populations.

Figure 2

Représentation des axes canoniques des 11 populations européennes d'Anguillicola crassus étudiées. Les deux premiers axes canoniques représentent respectivement $35,2 \%$ et $18,5 \%$ de l'inertie canonique totale. Les ellipses représentent l'intervalle de confiance à $95 \%$ autour des centroïdes. 1 = Suisse ; 6 et $7=$ Pays-Bas; $8=$ Suède; $10=$ Grèce; 11,12 et $13=$ Côtes Atlantiques Françaises ; 14, 15 et 16 = Côtes Méditerranéennes Françaises. Les numéros sont les mêmes que ceux du tableau I. Les cercles noirs représentent les populations méditerranéennes, les cercles blancs les autres populations. 
between the 11 populations $(p<0.01)$. The first four axes were significant and represented respectively $11.6 \%, 6.15 \%, 4.53 \%$ and $3.23 \%$ of the total inertia, and $35.2 \%, 18.5 \%$, $14,1 \%$ and $10.2 \%$ of canonical inertia (the variance between groups). The first axis of the analysis separated a group of 4 populations located around the Mediterranean Sea (10, 14, 15 and 16) from 5 populations situated on the Atlantic coast of France or in Holland $(6,7,11,12$ and 13). Populations from Sweden and Switzerland were isolated from these groups. The second axis discriminated the population of Switzerland on the positive half of the axis (1) from the population of Sweden (8) on the negative half.

In a second step, the 16 populations were analysed together. A series of 200 permutations on the two informative axis indicated that there was a significant differentiation between populations (Figure 3). The two first axis of the analysis explained respectively $29 \%$ and $13.3 \%$ of the canonical inertia. The first axis of the discriminating analysis separated the Mediterranean populations from all the other populations. Markers playing a major role in this differentiation were G17d and G05c. The second axis isolated the population of $A$. crassus from Switzerland (1) on one side and the populations from Sweden (8) and North-America (3) on the other side, from the other populations from outside the Mediterranean Sea. Markers G16c and G16h mainly contributed to explain the inertia of the second axis.

Mantel test carried out on the 16 populations did not detect any relationship between geographical distances and genetic distances based on RAPD markers $(p=0.79)$. We did not find any significant correlation between the genetic distances and the dates of introduction of $A$. crassus in the different sites of this work $(p=0.48)$ (according to MORAVEC, 1992; BLANC, 1994; RAHHOU et al., 2001 and KIRK, 2003). On the other hand, we observed a significant correlation between geographical distances and dates of introduction of $A$. crassus in the different sites of this work (Mantel test with 1000 permutations, $\mathrm{p}=0.03$ ).

\section{DISCUSSION}

The recent introduction of Anguillicola crassus in the European eel populations is supposed to be one of the main natural causes of mortality of this fish species (SURES and KNOPF, 2004). Pathological effects have been reported as thickening, fibrosis and inflammation of the epithelial cells of the swimbladder (WÜRTZ et al., 1996; WÜRTZ and TARASCHEWSKI, 2000). Many works have shown that the effects on the European eels are much more important than those on the native Japanese eel (MORAVEC and TARASCHEWSKI, 1988; KENNEDY and FITCH, 1990; KØIE, 1991; MOLNAR et al., 1991; KNOPF and MAHNKE, 2004; MÜNDERLE et al., 2004). The rapid spatial extension of Anguillicola crassus has been reported (KIRK, 2003). The aim of our study was to compare parasite populations from the original population (providing from Anguilla japonica) and from different places where the parasite is now found in abundance, in order to discuss the dynamic of the invasion.

Our results revealed that it is possible to genetically separate parasite populations from fish coming from around the Mediterranean Sea and parasites from fish coming from the Atlantic coast of France (Brittany) or Holland. The most northern sampled population (Sweden) and the more continental one (Switzerland) were also isolated. We hypothesize that the close relationship found between the parasites of the Atlantic coast of France and the one from Holland could be the result of a transfer of eels to Holland aquaculture firms. The separation of the Mediterranean populations may have been the result of a different event of introduction. However, no information is yet available and more detailed analysis (other molecular analysis, with a larger sample size and more populations for example) is still needed to answer the question of a multiple origin introduction of the parasite in Europe. The more continental position of Switzerland may explain the isolation of the 


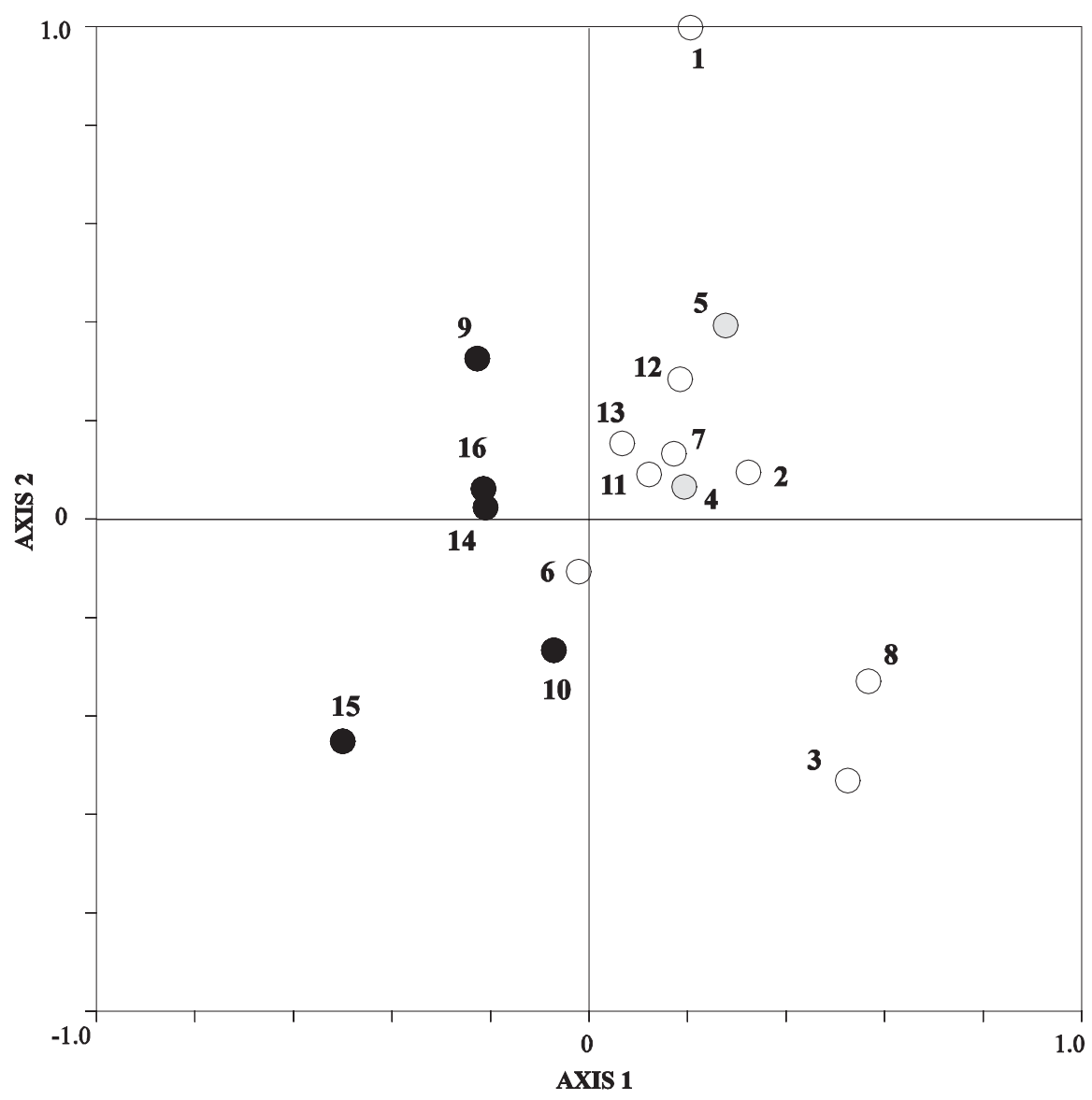

Figure 3

Canonical representation of the 16 populations of Anguillicola crassus studied. The two first axes represent respectively $29 \%$ and $13.3 \%$ of the canonical inertia. 1 = Switzerland; 2 and $3=$ North-America; 4 and $5=$ Japan; 6 and $7=$ Holland; 8 = Sweden; 9 = Morocco; 10 = Greece; 11, 12 and 13 = Atlantic coast of France; 14,15 and 16 = Mediterranean coast of France. Numbers are the same as in table I. Black dots represent Mediterranean populations, grey dots the two Japanese populations and white dots all other populations.

Figure 3

Représentation des axes canoniques des 16 populations d'Anguillicola crassus étudiées. Les deux premiers axes canoniques représentent respectivement $29 \%$ et $13,3 \%$ l'inertie canonique totale. 1 = Suisse; 2 et $3=$ Amérique du Nord; 4 et $5=$ Japon ; 6 et $7=$ Pays-Bas ; $8=$ Suède ; $9=$ Maroc ; $10=$ Grèce; 11,12 et $13=$ côtes atlantiques françaises; 14,15 et $16=$ côtes méditerranéennes françaises. Les numéros sont les mêmes que ceux du tableau I. Les cercles noirs représentent les populations méditerranéennes, les cercles gris les populations japonaises et les cercles blancs les autres populations.

A. crassus population in term of distance to the sea. The northern position of Sweden may explain the difference found in the studied parasites.

When comparing all the studied populations, the results revealed that $A$. crassus from Sweden and from North America (3) were grouped together. The first case of anguillicolosis in North America was reported from an aquaculture of south Texas and then 
reported in South Carolina (FRIES et al., 1996). However, no information is yet available on any translocation of host even if eel imports are highly suspected to be the responsible of the presence of $A$. crassus in North America (FRIES et al., 1996). The presence of A. crassus in North America could also be linked to a transfer of potential paratenic host species with water ballast of boat coming from Europe (THOMAS and OLLEVIER, 1992; RICCIARDI and MACISAAC, 2000). Our results may give some information on the relationship between worms from Sweden and from North America, but the original source of the worms in North America is still unknown as far as we know. Finally, parasites coming from Japanese eels were grouped with parasites from Northern Europe and the Atlantic coast of France. This result is consistent with the historical dynamic of the infestation, with an introduction in Germany and the rapid spread of the parasite in the rest of continental Europe.

We finally found a relationship between the geographical distances and the dates of introduction. This result gives an evidence of the rapid natural spread of the parasite through the studied area. This is confirmed by a lack of relationship between genetic distances and geographic distances and supports the hypothesis of multiple independent introductions in Europe. According to BLANC (1994), transfers of anthropological origin of eels but also of paratenic hosts may have largely contributed to the initial geographical extension of Anguillicola crassus in Europe. Despite a relative low gene exchange between parasite populations and a limited migration of parasites through natural definitive or paratenic hosts migration we did not found well established structured populations. This could be due either to the marker used or the evidence of frequent active transfers of eels.

As a conclusion, our understanding of the dynamic of the colonization of Europe by the parasite is now well known (see the abundant literature). However, only one recent work (LEFEBVRE and CRIVELLI, 2004) present a long term series of epidemiological data. However, there is still a need in long term studies to have a better estimation of the virulence evolution. Finally, despite the growing interest on the effect of $A$. crassus on the host physiology (KELLY et al., 2000; GOLLOCK et al., 2004; SURES and KNOPF, 2004), we still do not really know the consequences of the parasite on the gonad maturation, the trans oceanic migration for reproduction and the reproduction success of the European eel. These knowledges might be important in order to protect the eel populations in the close future.

\section{ACKNOWLEDGMENTS}

We would like to thank laboratories and people who answered so readily for sample request: K.J. MAIER, A. BARSE, O. HAENEN, H. WICKSTRÖM, C. BELPAIRE, J. VAN WILLIGEN, A. CRIVELLI, T. ARAI, A. YAHYAOUI, C. CLEVESTAM, J.L. ESTIRACH, Fédération AAPPMA 35. We are grateful to E. AMILHAT and E. JOBET for their technical assistance. The project has been financially supported by the GRISAM, ORME and the CNRS.

\section{REFERENCES}

BARRAL V., THIS P., IMBERT-ESTABLET D., COMBES C., DELSENY M., 1993. Genetic variability and evolution of the Schistosoma genome analysed by using random amplified polymorphic DNA markers. Molecular and Biochemical Parasitology, 59, 211-222.

BLANC G., 1994. Biologie du cycle d'Anguillicola crassus (Nematoda, Dracunculoidea), contrôle de ses populations. Thèse de Doctorat, Université de Perpignan, Perpignan, France 349 pp. 
EL HILALI M., YAHYAOUI A., SADAK A., MAACHI M., TAGHY Z., 1996. Premières données épidémiologiques sur l'anguillicolose au Maroc. Bulletin Français de la Pêche et de la Pisciculture, 340, 57-60.

FRIES L.T., WILLIAMS D.J., JOHNSON S.K., 1996. Occurrence of Anguillicola crassus, an exotic parasite swimbladder nematode of eels, in the southeastern United States. Transaction of the American Fisheries Society, 125, 794-797.

GOLLOCK M.J., KENNEDY C.R., QUABIUS, E.S., BROWN J.A., 2004. The effect of parasitism of European eels with the nematode Anguillicola crassus on the impact of netting and aerial exposure. Aquaculture, 233, 45-54.

KELLY C.E., KENNEDY C.R., BROWN J.A., 2000. Physiological status of wild European eels (Anguilla anguilla) infected with the parasitic nematode, Anguillicola crassus. Parasitology, 120, 195- 202.

KENNEDY C.R., FITCH D.J., 1990. Colonisation, larval survival and epidemiology of the nematode Anguillicola crassus, parasitic in eel, Anguilla anguilla, in Britain. Journal of Fish Biology, 36, 117-131.

KIRK R.S., 2003., The impact of Anguillicola crassus on European eels. Fisheries Management and Ecology, 10, 385-394.

KJØLNER S., SÅSTAD S. M., TABERLET P., BROCHMANN C., 2004. Amplified fragment length polymorphism versus random amplified polymorphic DNA markers: clonal diversity in Saxifraga cernua. Molecular Ecology, 13, 81-86.

KNOPF, K., MAHNKE, M., 2004. Differences in susceptibility of the European eel (Anguilla anguilla) and the Japanese eel (Anguilla japonica) to the swim-bladder nematode Anguillicola crassus. Parasitology, 129, S491-S496.

KØIE M., 1988. Parasites in eels Anguilla anguilla (L.) from Danish freshwater, brackish and marine localities. Ophelia, 29, 93-118.

KØIE M., 1991. Swimbladder nematodes (Anguillicola spp.) and gill monogeneans (Pseudactylogyrus spp.) parasitic of the European eel (Anguilla anguilla). Journal du Conseil International pour l'Exploration de la Mer, 47, 391-398.

KOOPS H., HARTMANN F., 1989. Anguillicola infestations in Germany and in German eel imports. Journal of Applied Ichthyology, 1, 41-45.

KREBS, C.J. 1999. Ecological Methodology. Harper and Collins, New-York, 654 pp.

LANGAND J., THÉRON A., POINTIER J.P., DELAY B., JOURDANE J., 1999. Population structure of Biomphalaria glabrata intermediate snail host of Schistosoma mansoni in Guadeloupe Island, using RAPD markers. Journal of Molluscan Studies, 65, 425433.

LEFEBVRE, F., CONTOURNET, P., CRIVELLI, A.J., 2002. The health state of the eel swimbladder as a measure of parasite pressure by Anguillicola crassus. Parasitology, 124, 457- 463.

LEFEBVRE F.S., CRIVELLI A.J., 2004. Anguillicolosis: dynamics of the infection over two decades. Diseases of Aquatic Organisms, 62, 227-32.

MOLNAR K., SZEKELY C., BASKA F., 1991. Mass mortality of eel in Lake Balaton due to Anguillicola crassus infection. Bulletin of the European Association of Fish Pathologists, 11, 211-212.

MORAVEC F., 1992. Spreading of the nematode Anguillicola crassus (Dracunculoidea) among eel populations in Europe. Folia Parasitologia, 39, 247-248.

MORAVEC F., 1996. Aquatic invertebrates (snails) as new paratenic hosts of Anguillicola crassus (Nematoda: Dracunculoidea) and the role of paratenic hosts in the life cycle of this parasite. Diseases of Aquatic Organisms, 3, 237-239. 
MORAVEC F., TARASCHEWSKI H., 1988. Revision of the genus Anguillicola Yamaguti, 1935 (Nematoda: Anguillicolidae) of the swim bladder of eels, including descriptions of two new species, $A$. novaezelandiae sp. N. and $A$. papaernae sp. N. Folia Parasitologia, 35, 125-146.

MÜNDERLE M., SURES B., TARASCHEWSKI H., 2004. Influence of Anguillicola crassus (Nematoda) and Ichthyophthirius multifilis (Ciliophora) on swimming activity of European eel Anguilla anguilla. Diseases of Aquatic Organisms, 60, 133-139.

NEUMANN W., 1985. Schwimmblasenparasit Anguillicola bei Aalen. Fischer und Teichwirt, $11,322$.

PETERS G., HARTMANN F., 1986. Anguillicola, a parasitic nematode of the swim bladder spreading among eel populations in Europe. Diseases of Aquatic Organisms, 1, 229-230.

RAHHOU I., MELHAOUI M., LECOMTE-FINIGER R., MORAND S., CHERGUI H., 2001. Abundance and distribution of Anguillicola crassus (nematoda) in eels Anguilla anguilla from Moulouya Estuary (Morocco). Helminthologia, 38, 93-97.

RICCIARDI A., MACISAAC H.J., 2000. Recent mass invasion of the North American Great Lakes by Ponto-Caspian species. Trends in Ecology and Evolution, 15, 62-65.

SURES B., KNOPF K., 2004. Parasites as a threat to freshwater eels? Science, 304, 209211.

TER BRAAK C.J.F., 1986. Canonical correspondence analysis: a new eigenvector technique for multivariate direct gradient analysis. Ecology, 67, 1167-1179.

THOMAS K., OLLEVIER F., 1992. Population biology of Anguillicola crassus in the final host Anguilla anguilla. Diseases of Aquatic Organisms, 14, 163-170.

WELSH J., MCCLELLAND M., 1990. Fingerprinting genomes using PCR with arbitrary primers. Nucleic Acids Research, 18, 7213-7218.

WILLIAMS J.G.K., KUBELIK A.R., LIVAK K.J., RAFALSKI J.A., TINGEY S.V., 1990. DNA polymorphisms amplified by arbitrary primers are useful as genetic markers. Nucleic Acids Research, 18, 6531-6535.

WÜRTZ J., TARASCHEWSKI H., 2000. Histopathological changes in the swimbladder wall of the European eel Anguilla anguilla due to infections with Anguillicola crassus. Diseases of Aquatic Organisms, 39, 121-134.

WÜRTZ J., TARASCHEWSKI H., PELSTER B., 1996. Changes in gas compositions in the swimbladder of the European eel (Anguilla anguilla) infected with Anguillicola crassus (Nematoda). Parasitology, 112, 233-238. 